\title{
Mobile Banking Choices of Entrepreneurs: A Unified Theory of Acceptance and Use of Technology (UTAUT) Perspective
}

\author{
Ashish Varma \\ Institute of Management Technology, Ghaziabad, India \\ Email:avarma@imt.edu
}

How to cite this paper: Varma, A. (2018) Mobile Banking Choices of Entrepreneurs: A Unified Theory of Acceptance and Use of Technology (UTAUT) Perspective. Theoretical Economics Letters, 8, 2921-2937. https://doi.org/10.4236/tel.2018.814183

Received: August 23, 2018

Accepted: October 17, 2018

Published: October 20, 2018

Copyright $\odot 2018$ by author and Scientific Research Publishing Inc. This work is licensed under the Creative Commons Attribution International License (CC BY 4.0).

http://creativecommons.org/licenses/by/4.0/

\section{(c) (7) Open Access}

\begin{abstract}
This study applies the unified theory of acceptance and use of technology (UTAUT) to investigate the entrepreneurial usage of mobile banking services. The study was conducted during 2017-18 using a partial least squares-structural equation modeling technique. A sample of 206 entrepreneurs, from fourteen sub-urban towns in India, was studied. The study found that mobile banking intentions mediates the relationship between all three; effort expectancy and use behavior, performance expectancy and use behavior and social influence and use behavior. There was no gender-based difference between the banking behavior among the entrepreneurs. The study also validates the UTAUT theory in an emerging market context. These findings are significant as the entrepreneurial choices regarding mobile banking in emerging markets demands more research. Mobile phones have a deep penetration in the emerging markets and so its role in facilitating the banking needs of the entrepreneurs should be ascertained. The study also contributes to the methods by illustrating the use of importance performance map analysis (IPMA) in the UTAUT context.
\end{abstract}

\section{Keywords}

UTAUT, Entrepreneur, Mobile Banking, India, PLS-SEM

\section{Introduction}

This study aims to ascertain the use of mobile banking technology by the entrepreneurs. The significance of the study can be judged from the fact that research in this domain is lacking in evidence from emerging markets [1]. Entrepreneurs innovate in their businesses and also consume innovative services in the process 
of running their businesses. As per Alawan et al. [2], mobile banking is one of the most innovative technologies which enables banking at the time and place where the customers want and they further state that the rapid increase in mobile banking was due to advancements in both the mobile and telecommunication technologies. Here, mobile banking refers to banking activities conducted through mobile internet technologies [3]. Mobile banking is user friendly due to the portability of the device, widely available telecom networks and flexibility of use [4]. The mobile banking experience covers the entire gamut of banking services such as money transfer, bill payment, loans, deposits etc. and these are useful for the entrepreneurs as they may need mobile banking services in remote places and at odd hours.

The choice of suburban Indian towns was made to ascertain whether the mobile banking technology has witnessed inclusive acceptance from entrepreneurs across the country and was not limited only to big cities. Banks have invested significant resources in mobile banking. The study of mobile banking in suburban Indian towns tells us penetration and acceptance of technology across the country. Unlike big cities, suburban regions are characterized by lack of not only internet connectivity but also traditional bank branches [5]. Cruz et al. [6] found mobile banking as a viable option in these regions. Thus, there is a strong need to promote mobile banking adoption in suburban India.

Entrepreneurs face several challenges in an emerging market. For them technology could offer best solutions. Lee et al. [7] enlisted the key parameters for which the customers perceived mobile banking as a viable choice for their banking needs. Mobile banking, if perceived to be less risky [8] could potentially mitigate the geographical and institutional constraints faced by entrepreneurs especially in suburban towns of India. This in turn would contribute to nation building by encouraging more inclusive growth. Similar to the risk taking managers' ability to counterbalance the effect of limiting organizational controls to innovate [9], was it also possible that entrepreneurs could also manage to mitigate the institutional and geographical challenges by using innovative banking solutions such as mobile banking? Hence there was a need to empirically probe into the mobile banking choices of entrepreneurs.

The reach of mobile banking is expected to substantially increase in the future. Initially, mobile banking had not been adopted as per expectations in the developing countries and the customers were not too enthusiastic about its utility [10]. Thus, the challenge was to create a customer engagement and ensure customer buy in for the use of mobile banking [11]. Wessels and Drennan [12] stated that customers demanded that mobile banking should be less expensive, more convenient to use and relevant to their everyday needs. Yang [13] identified security concerns and cost as the major bottlenecks for adoption of mobile banking.

The study had the theoretical underpinnings of the unified theory of acceptance and use of technology (UTAUT) [14]. There was a need to study the use of 
technology, which could be a great equalizer in the ease of financial transactions in the tier two cities, in an emerging market such as India. Primary data was analyzed with PLS SEM methodology. The key findings of the study were that performance expectancy had the highest effect on the behavioral intention to use mobile banking followed by effort expectancy and social influence, respectively. The facilitating conditions, it was observed, did not impact the use behavior of mobile banking. It was also observed that behavioral intention mediated the relationship between the constructs effort expectancy and use behavior, performance expectancy and use behavior and social influence and use behavior.

The paper is structured as follows. After the introduction, in Section two the conceptual development and hypothesis testing is discussed in detail. Section three is dedicated to the methods and the results are shown in Section four. This is followed by the discussion and the conclusion in Section five and Section six respectively.

\section{Conceptual Development and Hypothesis Testing}

Prior studies have highlighted that entrepreneurs face all kinds of challenges, financial, legal or even personal [15] and that these challenges impact their eventual choice of use of information system innovations in their businesses [16]. However, there is insufficient research on the mobile banking choices of entrepreneurs, especially in a promising emerging market such as India. This study bridges this gap. Mobile banking allows the entrepreneur to have anytime and anywhere access to their banking transactions which saves their precious time, and offers them better business possibilities [16]. These better business possibilities are captured in the UTAUT construct of performance expectancy. Munoz-Leiva et al. [17] highlighted the possibilities that mobile banking promises due to the remote banking services. Other studies such as those by Franquesa and Brandyberry [18] and Spencer et al. [19] have also improved our understanding of the factors which effect the adoption of this technology by entrepreneurs although this domain still leaves many questions unanswered.

The UTAUT was originally devised to be used in the context of employee acceptance of technology [20] however it has since been used extensively in the context of consumer studies. Williams et al. [21] highlighted, UTAUT was popular in the domain of information communication and technology (ICT). More specifically in the mobile banking space, UTAUT has been extensively been used Zhou et al. 2010 [22] and in the internet banking space Riffai et al. [23]. Zhou et al. [22] defined mobile banking as the use of cell phones to access the banking network and this study builds on Zhou's definition of mobile banking.

The UTAUT [14] model is both compressive and relevant for the mobile banking adoption intentions of entrepreneurs. In this study, the construct performance expectancy measures the extent of the entrepreneurs' belief that the use of the technology will improve the business performance and hence is value adding. The construct effort expectancy captures the degree of ease with which 
the technology can be used for the intended business operation. Social influence construct, measures the extent of significance which is placed on the opinion of outsiders (outsiders who are important to the entrepreneur) regarding the entrepreneurs' use of the new technology. Finally, the facilitating conditions captures the degree to which the entrepreneur thinks that the support ecosystem exists for the entrepreneur to use to new technology. UTAUT presumes that facilitating conditions construct can measure the environmental influence that have a bearing on the actual behavior.

UTAUT posits that the three constructs namely effort expectancy, performance expectancy and social influence directly have an effect on the behavioral intention towards, say towards the use of mobile banking technology. It also posits that the two constructs behavioral intention and facilitating conditions have a direct effect on the actual usage of mobile banking technology. Venkatesh et al. [24] further advocated the study of intrinsic motivation of the customers to adopt mobile banking and Dodd et al. [25] highlighted the customer's behavior of measuring both the utility and the cost of using innovations. Similar other studies concluded that use of internet and other information and communication technologies (ICTs), enable firms to gain competitive advantage [26]. The above discussion leads to the following hypothesis:

H1: The behavioral intention to use mobile banking positively affects the use of mobile banking by entrepreneurs.

H2: The effort expectancy in the use of mobile banking positively affects the intention to use mobile banking by entrepreneurs.

H3: The facilitating conditions perceived in the use of mobile banking positively affect the use of mobile banking by entrepreneurs.

H4: The performance expectancy of mobile banking positively affects the intention to use mobile banking by entrepreneurs.

H5: The social influence regarding mobile banking positively affects the intention to use mobile banking by entrepreneurs.

H6: The behavioral intention mediates the relationship between effort expectancy and use behavior.

H7: The behavioral intention mediates the relationship between performance expectancy and use behavior.

H8: The behavioral intention mediates the relationship between social influence and use behavior.

\section{Methods}

The methods used for the study were carefully chosen to best address the research's requirements. The study was thus positivist in nature, and used a quantitative survey method. The data collection method was tailored to suit the specific research question of the study.

\subsection{Data Collection, Research Setting, and Sample}

The hypothesis of the study based on the theoretical underpinning of the 
UTAUT was tested on entrepreneurs from 14 Indian sub urban towns. This was undertaken to make the results relevant and generalizable to a larger audience [27]. The suburban region was defined as per the guidelines of the Reserve Bank of India (RBI) [28] which states that a suburban bank branch is defined as one which serves a population of 10,000 people or more but less than 100,000 people. Thus, towns with such a population range were considered as "sub urban" for this study. It was ensured by a careful study, that these suburban townships represent the diversity of the entrepreneurial ventures of India and thus the data was collected from eight states of India.

The face validity of the questionnaire was established by taking the inputs from four academicians and three industry experts. The questionnaire was pretested [29] and a pilot study was conducted to validate it [30] before it was administered to the entrepreneurs. The questionnaire was properly labeled and it used a seven-point self-rating, Likert scale to maximize the variances. The Likert scale ranging from 1 (strongly disagree) to 7 (strongly agree) was used. This was as per the process advocated by Churchill and Lacobucci [31] for measuring the variables which are not directly observed. The questionnaire was administered to 700 entrepreneurs and after screening out the incomplete questionnaires, a total of 206 useful and complete questionnaires were obtained. Therefore, the response rate was $29.42 \%$. The hard copy of the questionnaire was used and a follow up procedure was also carried out to the unresponsive entrepreneurs. In order to get authentic responses, the entrepreneurs were assured that the responses would be used for research purposes only. The sample (Table 1) of 206 respondents was $26.21 \%$ female.

A complete procedure as suggested by Podsakoff et al. (2003) [32] was followed to control the common method variance. At the data collection stage, all the entrepreneurs were fully assured of complete anonymity of their responses and that the data collected would be used for academic research purposes only. They were also told that there was no right or wrong answer to any of the questions.

\subsection{Statistical Analysis}

For hypothesis testing purposes, a partial least-square structural equation model (PLS-SEM) was adopted. PLS-SEM was the contextually appropriate choice since

Table 1. Description of Sample, $\mathrm{n}=206$.

\begin{tabular}{ccc}
\hline Variable & Variable & $\%$ \\
\hline \multirow{2}{*}{ Age of the Entrepreneur } & $20-30$ & $67.96 \%$ \\
& 31 and above & $32.04 \%$ \\
Gender & Male & $73.79 \%$ \\
& Female & $26.21 \%$ \\
Industry Category & Manufacturing, Assembly & $46.60 \%$ \\
& Trading, Services, Operations, Logistics & $53.40 \%$ \\
\hline
\end{tabular}


it did not require any parametric condition [29] and also did away with the limitation of small sample size [33]. PLS SEM is a non-parametric multivariate technique which has gained much recognition in the academia. The Smart PLS package version 3.2.7 [34] was used for data analysis. As per Lowry and Gaskin [35], PLS-SEM measures the measurement model and the structural model at the same time. All the figures were conceptualized and the relevant calculations made, by the author, in the Smart PLS package version 3.2.7. All the tables were also derived from the same package and reformatted in MS word by the author.

\subsection{Measurement Variables}

The scales for the UTAUT model were taken from Escobar-Rodriguez and Carvajal-Trujillo [20] and the words in the questions were slightly modified to suit the context but without changing the meaning and the perspective. Performance expectancy and effort expectancy were measured using four items and social influence and facilitating conditions were measured using three items. Behavioral intention was measured using three items and the usage behavior was measured by a single question regarding the actual usage of mobile banking. A few of the questions were re-worded as per the learnings from the pilot test. The questionnaire was also translated into the Hindi language, so that a larger group of respondents could be reached out for the purpose of the survey. A professional translator was asked to translate the questionnaire so that both the context and the meaning could be retained. The validity and the reliability of the scales was established before undertaking the data analysis. Only the fully complete questionnaires were considered for the purpose of the study.

\section{Results}

As per Ali and Park [36], the process involved the measurement model assessment and then the structural model assessment. All the constructs were needed to be well measured to be used for the structural model evaluation.

\subsection{Evaluation of Measurement Model}

All the six constructs in the model were measured reflectively (Table 2). The composite reliability (CR) was calculated to measure the internal consistency of the constructs. The CR was greater than 0.7 for all the constructs. The outer loadings were significant and found to be higher than 0.7. Average variance extracted (AVE) which is a measure of convergent validity was found to be greater than 0.5 and significant at $95 \%$ level. The discriminant validity was established using the criteria of Heterotrait Monotrait (HTMT) ratio (Table 3). This criterion is the strictest amongst the other two criteria for discriminant validity viz. cross loading criteria and the Fornell and Larker [37] criteria. The discriminant validity was established since all the values were below 0.85 . Only between the constructs performance expectancy and facilitating conditions was the value 0.852 which was considered acceptable as it was very close to 0.85 and therefore retained. 
Table 2. Reliability and validity.

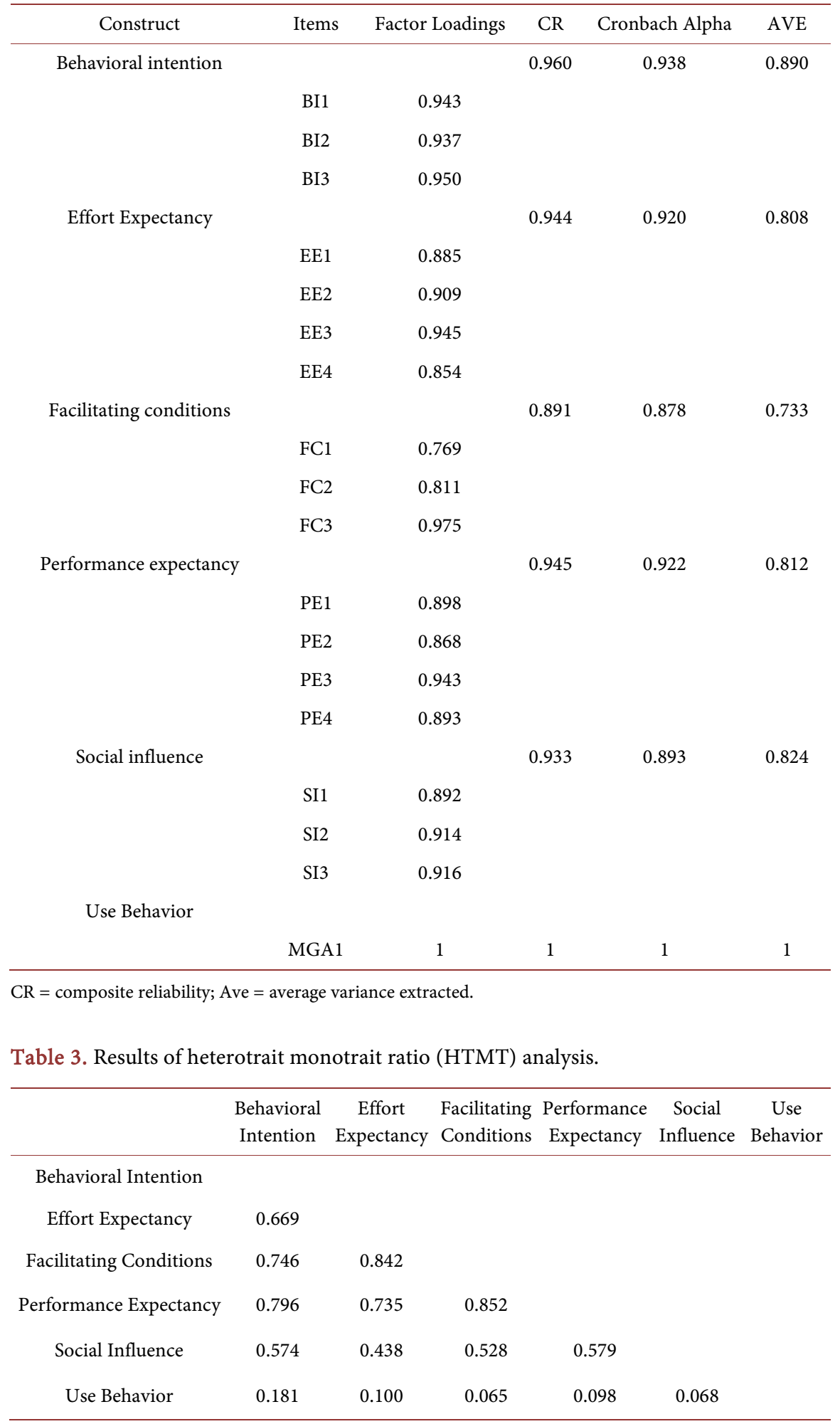

\subsection{Evaluation of Structural Model}

As per Sarstedt et al. [38], collinearity assessment needs to be carried out before the structural model evaluation. Towards this end, the variance inflation factor 
(VIF) for each of the construct items was ascertained (Table 4 and Table 5). VIF is the reciprocal value of tolerance [39]. Since the VIF was less than 5 for all the items except EE3 and PE3 (which was marginally above 5 and hence retained due to theoretical choice), there was no collinearity concern in the data.

The path coefficients (Figure 1) are ascertained after running the PLS algorithm. The algorithm is designed to reject a set of path specific null hypothesis of no effect. The "R square" value is given in Table 6. As per Table 6, r-square for the construct behavioral intentions is 0.6 and significant, coefficient of determination. Also, the path coefficient from behavioral intention, to use behavior, was both strong and significant.

The study highlighted that the construct performance expectancy had the highest effect $\left(\beta=0.507^{* * *}, \mathrm{t}=6.508\right)$ on the intention to use mobile banking followed by effort expectancy $\left(\beta=0.207^{* * * *}, \mathrm{t}=3.311\right)$ and social influence $(\beta=$ $0.179^{* * *}, \mathrm{t}=2.748$ ), respectively (Table 7 ). This finding can be attributed to the fact that the present study was based on the entrepreneurs and to them, performance meant more than any other factor. The facilitating conditions, it was observed, do not impact the use behavior of mobile banking. Quite interestingly, it was observed that behavioral intention mediates the relationship between the constructs effort expectancy and use behavior, performance expectancy and use behavior and social influence and use behavior. This is because as per theory, significant indirect effects using bootstrapping mean significant mediation (Preacher and Hayes 2008) [40]. Also, as per Preacher and Hayes (2008) [40],

Table 4. Outer VIF values.

\begin{tabular}{cl}
\hline Outer VIF Values & VIF \\
\hline BI1 & 4.128 \\
BI2 & 3.873 \\
BI3 & 4.635 \\
EE1 & 2.829 \\
EE2 & 3.810 \\
EE3 & 5.171 \\
EE4 & 2.321 \\
FC1 & 2.948 \\
FC2 & 3.106 \\
FC3 & 1.933 \\
MGA1 & 1.000 \\
PE1 & 2.850 \\
PE2 & 2.761 \\
PE3 & 5.494 \\
PE4 & 3.681 \\
SI1 & 2.354 \\
SI2 & 3.082 \\
SI3 & 2.799 \\
\hline
\end{tabular}


Table 5. Inner VIF values.

\begin{tabular}{|c|c|c|c|c|c|c|}
\hline Inner VIF Values & $\begin{array}{l}\text { Behavioral } \\
\text { Intention }\end{array}$ & Effort Expectancy & $\begin{array}{l}\text { Facilitating } \\
\text { Conditions }\end{array}$ & $\begin{array}{l}\text { Performance } \\
\text { Expectancy }\end{array}$ & Social Influence & Use Behavior \\
\hline Behavioral Intention & & & & & & 2.237 \\
\hline Effort Expectancy & 1.863 & & & & & \\
\hline Facilitating Conditions & & & & & & 2.237 \\
\hline Performance Expectancy & 2.174 & & & & & \\
\hline Social Influence & 1.389 & & & & & \\
\hline Use Behavior & & & & & & \\
\hline
\end{tabular}

Table 6. Coefficient of determination.

\begin{tabular}{cccc}
\hline R Square & Original Sample $(\mathrm{O})$ & T Statistics $(|\mathrm{O} / \mathrm{STDEV}|)$ & $\mathrm{P}$ Values \\
\hline Behavioral Intention & $0.600^{* * * *}$ & 9.166 & 0.000 \\
Use Behavior & $0.033^{*}$ & 1.798 & 0.073 \\
\hline
\end{tabular}

n.s. not-significant; ${ }^{*}|\mathrm{t}| \geq 1.65$ at $\mathrm{p}=0.10$ level; ${ }^{* *}|\mathrm{t}| \geq 1.96$ at $\mathrm{p}=0.05$ level; ${ }^{* *}|\mathrm{t}| \geq 2.58$ at $\mathrm{p}=0.01$ level; ${ }^{* * *}|\mathrm{t}| \geq 3.29$ at $\mathrm{p}=0.001$ level.

Table 7. Significant individual path coefficients in the structural model.

\begin{tabular}{|c|c|c|c|c|}
\hline Structural Path & $\begin{array}{l}\text { Path Coefficient } \\
\text { (t value) }\end{array}$ & $\mathrm{p}$ values & $\begin{array}{l}\text { Effect size } \\
\text { (f square) }\end{array}$ & Conclusion \\
\hline Behavioral Intention -> Use Behavior & $\begin{array}{c}0.232 \\
(3.157)\end{array}$ & 0.002 & 0.025 & $\mathrm{H} 1$ is supported. \\
\hline Effort Expectancy -> Behavioral Intention & $\begin{array}{c}0.207 \\
(3.311)\end{array}$ & 0.001 & 0.057 & $\mathrm{H} 2$ is supported. \\
\hline Facilitating Conditions -> Use Behavior & $\begin{array}{l}-0.075 \\
(0.779)\end{array}$ & 0.436 & 0.003 & H3 is not supported. \\
\hline Performance Expectancy -> Behavioral Intention & $\begin{array}{l}0.507 \\
(6.508)\end{array}$ & 0.000 & 0.296 & H4 is supported. \\
\hline Social Influence $->$ Behavioral Intention & $\begin{array}{c}0.179 \\
(2.748)\end{array}$ & 0.006 & 0.058 & H5 is supported. \\
\hline $\begin{array}{l}\text { Effort Expectancy }->\text { Behavioral Intention } \\
->\text { Use Behavior }\end{array}$ & $\begin{array}{c}0.048 \\
(2.269)\end{array}$ & 0.024 & - & $\begin{array}{l}\text { H6 is supported. } \\
\text { The mediating effect of behavioral } \\
\text { intention is established. }\end{array}$ \\
\hline $\begin{array}{l}\text { Performance Expectancy }->\text { Behavioral Intention } \\
->\text { Use Behavior }\end{array}$ & $\begin{array}{c}0.117 \\
(2.890)\end{array}$ & 0.004 & - & $\begin{array}{l}\text { H7 is supported. } \\
\text { The mediating effect of behavioral } \\
\text { intention is established. }\end{array}$ \\
\hline $\begin{array}{l}\text { Social Influence }->\text { Behavioral Intention } \\
->\text { Use Behavior }\end{array}$ & $\begin{array}{c}0.042 \\
(2.182)\end{array}$ & 0.030 & - & $\begin{array}{l}\text { H8 is supported. } \\
\text { The mediating effect of behavioral } \\
\text { intention is established. }\end{array}$ \\
\hline
\end{tabular}

n.s. not-significant; ${ }^{*}|\mathrm{t}| \geq 1.65$ at $\mathrm{p}=0.10$ level; ${ }^{* *}|\mathrm{t}| \geq 1.96$ at $\mathrm{p}=0.05$ level; ${ }^{\star * *}|\mathrm{t}| \geq 2.58$ at $\mathrm{p}=0.01$ level; ${ }^{\star * * *}|\mathrm{t}| \geq 3.29$ at $\mathrm{p}=0.001$ level.

there was no requirement to test direct effect before and after including the mediator.

A blindfolding procedure (Table 8) was carried out to ascertain the degree of predictive relevance of the exogenous construct for the endogenous construct use behavior which was measured reflectively. The $\mathrm{Q}$ square value [38] was greater than 0 and thus the model has predictive relevance. Also, a significant amount of variance is explained by the model. 


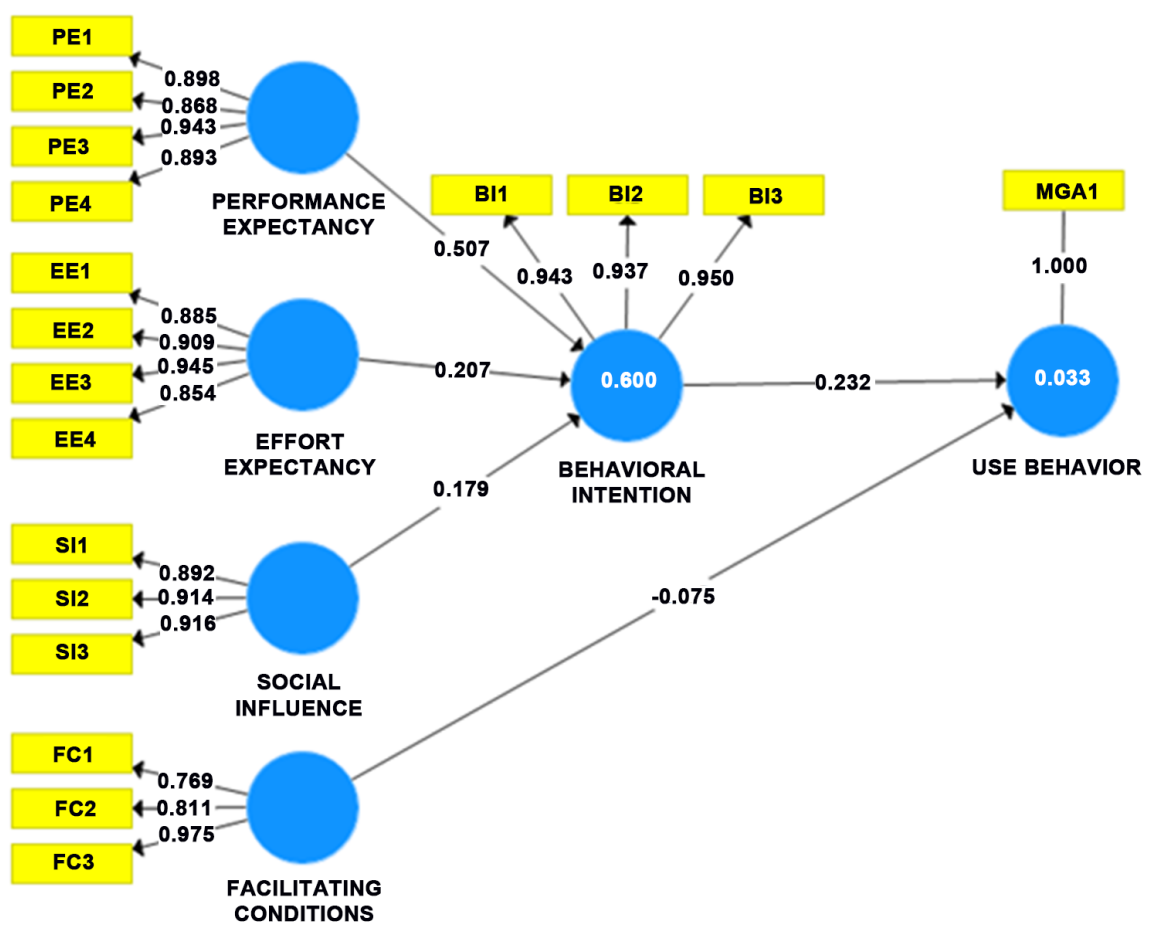

Figure 1. The structural model.

Table 8. Blindfolding.

\begin{tabular}{cccc}
\hline Total & SSO & SSE & $\mathrm{Q}^{2}(=1-$ SSE $/$ SSO $)$ \\
\hline Behavioral Intention & 618.000 & 207.023 & 0.665 \\
Effort Expectancy & 824.000 & 312.948 & 0.620 \\
Facilitating Conditions & 618.000 & 364.887 & 0.410 \\
Performance Expectancy & 824.000 & 318.500 & 0.613 \\
Social Influence & 618.000 & 264.953 & 0.571 \\
Use Behavior & 206.000 & & 1.000
\end{tabular}

\subsection{Test for Goodness of Fit}

The goodness of fit measure was ascertained as per Henseler and Sarstedt (2013) [41]. The standardized root mean square residual (SRMR) was 0.049 which was well below the threshold limit of 0.14 . Thus, the model was an overall good fit (Table 9).

\subsection{Importance-Performance Map Analysis (IPMA)}

The construct "social influence" was found not to be the most impactful construct (total effect $=0.042)($ Table 10$)$. However, the performance of this construct (Table 11) as ascertained by IPMA was 70.563. This means that the potential for improvement was the highest for this construct. Thus, in actionable terms, banks, for obtaining the maximum returns on their mobile banking initiatives, could focus on "socially influencing" the entrepreneurs. The other 
Table 9. Standardized root mean square residual.

\begin{tabular}{ccc}
\hline Fit Summary & Saturated Model & Estimated Model \\
\hline SRMR & 0.049 & 0.050 \\
\hline
\end{tabular}

Table 10. Construct total effects for [Use Behavior].

\begin{tabular}{cc}
\hline & Use Behavior \\
\hline Behavioral Intention & 0.232 \\
Effort Expectancy & 0.048 \\
Facilitating Conditions & -0.075 \\
Performance Expectancy & 0.117 \\
Social Influence & 0.042 \\
\hline
\end{tabular}

Table 11. Construct performances for [Use Behavior].

\begin{tabular}{cc}
\hline & Performances \\
\hline Behavioral Intention & 80.596 \\
Effort Expectancy & 82.461 \\
Facilitating Conditions & 85.097 \\
Performance Expectancy & 86.130 \\
Social Influence & 70.563 \\
\hline
\end{tabular}

constructs (Figure 2) were largely the same in their performance which was another reason for the banks to focus on socially influencing the entrepreneurs.

\subsection{Multi Group Analysis (MGA) on the Basis of Gender}

One important aspect of the study was to ascertain the gender-based difference in the entrepreneurial intention to use mobile banking. As per Morris et al. [42], the difference between the behavior of the gender is worth ascertaining. Thus, a multi group analysis (MGA) was carried out to ascertain whether the mobile banking usage results differ based on gender of the entrepreneur. As per the "Parametric test" (Table 12) there was no gender based difference among the entrepreneurs in their intention and usage of mobile banking.

\section{Discussion}

The Information and Communication Technologies (ICT) in banking have led to personalization of services and cost reductions [43] [44] which in turn was expected to lead to higher mobile banking adoption rates. This study aims to answer the question whether the entrepreneurs find mobile banking an attractive proposition for their business needs. This study applies the UTAUT in the context of mobile banking. UTAUT was contextually more suitable than similar theories such as the Technology Acceptance Model (TAM) [45], the Theory of 


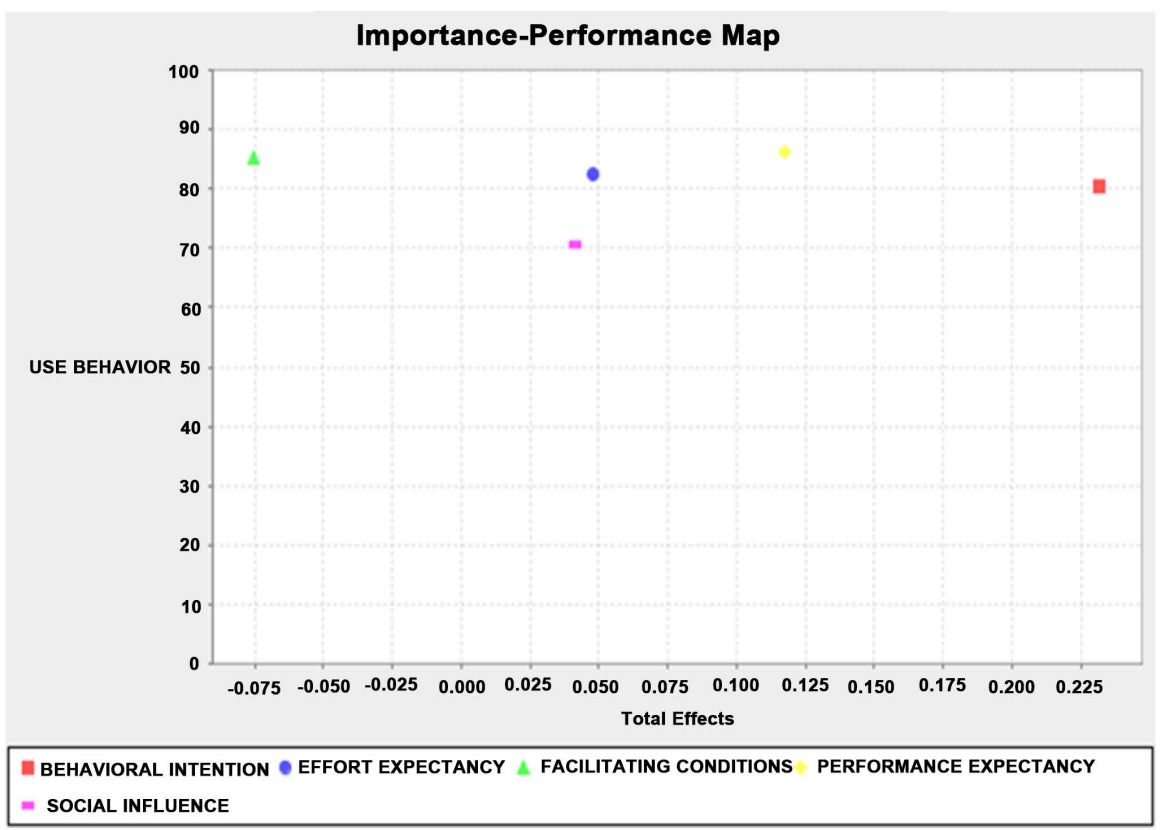

Figure 2. IPMA graph.

Table 12. Parametric test for MGA on the basis of gender of the entrepreneur.

\begin{tabular}{cc}
\hline & Path Coefficient Difference \\
\hline Behavioral Intention $->$ Use Behavior & $0.086 \mathrm{n} . \mathrm{s}$ \\
Effort Expectancy $->$ Behavioral Intention & $0.003 \mathrm{n} . \mathrm{s}$ \\
Facilitating Conditions -> Use Behavior & $0.069 \mathrm{n} . \mathrm{s}$ \\
Performance Expectancy -> Behavioral Intention & $0.263 \mathrm{n} . \mathrm{s}$ \\
Social Influence $->$ Behavioral Intention & $0.27 \mathrm{n} . \mathrm{s}$ \\
\hline
\end{tabular}

n.s. not-significant; ${ }^{*}|\mathrm{t}| \geq 1.65$ at $\mathrm{p}=0.10$ level; ${ }^{* *}|\mathrm{t}| \geq 1.96$ at $\mathrm{p}=0.05$ level; ${ }^{* *}|\mathrm{t}| \geq 2.58$ at $\mathrm{p}=0.01$ level; $* * * *|t| \geq 3.29$ at $p=0.001$ level.

Planned Behavior (TPB) [46] and the Innovation Diffusion Theory (IDT) [47]. This study extends the knowledge beyond Moghavvemi et al. [16] who studied the entrepreneur's adoption of information system innovation by using the UTAUT and the Entrepreneurial Potential Model (EPM) and Munoz-Leiva et al. [17] who demonstrated that attitude determined the intended use of mobile banking. This study clearly highlights as to what drives the entrepreneurial intention to use mobile banking.

The most significant theoretical contribution is the study of the mobile banking practices of entrepreneurs with the help of a strong theoretical model such as UTAUT and by the application of advanced methods such as PLS SEM. The model was well measured and was a good fit. The $r$-square value of the construct behavioral intention was 0.6 and significant which was similar to other studies such as those of Munoz-Leiva et al. [17]. This connotes that a significant portion of the change in the dependent variable behavioral intention could be explained by the independent variables namely performance expectancy, effort expectancy 
and social influence. In relation to the path coefficient analysis, the path from behavioral intention of using mobile banking to the actual use behavior was 0.232 and significant. This validated the UTAUT which posits that entrepreneurial intention would lead to actual behavior to adopt mobile banking in suburban India.

This study has certain limitation as well. The sample size was limited as the data was collected from selected towns of suburban India neglecting many entrepreneurs in other geographical regions. Further, the preferences, beliefs of the entrepreneurs also change as time goes by Lee et al. [48]. Finally, there exists the possibility of a gap between the intention and the actual behavior. The actual use of mobile banking was beyond the scope of the present study and is an area for future research.

Overall, the study makes significant theoretical, managerial and methodological contributions. The UTAUT was validated in a suburban sttings which is an emerging market. This study contributes to the literature a new knowledge that there is no gender based difference in the entrepreneurial adoption of mobile banking in an emerging market. This also has significant ramifications for banks who should design their mobile banking services with a universal appeal. Since the IPMA results suggest a focus on social influence, banks could focus on "socially influencing" all the entrepreneurs for getting the maximum returns on their mobile banking initiatives. Finally, from a methods viewpoint, all three specific indirect effects were found to be significant. This connotes mediation as per Preacher and Hayefs (2008) [40]. The study also illustrates the use of IPMA map and multi group analysis in validating the UTAUT.

\section{Conclusion}

Mobile banking is the way banking will be done in future. This study was conducted during 2017-18 using a partial least squares-structural equation modeling technique on a sample of 206 entrepreneurs from fourteen suburban towns in India. The study found that mobile banking intentions mediate the relationship between all three, effort expectancy and use behavior, performance expectancy and use behavior and social influence and use behavior. There was no gender-based difference between the banking behavior among the entrepreneurs. Finally, the study also validates the UTAUT theory in an emerging market context.

\section{Conflicts of Interest}

The authors declare no conflicts of interest regarding the publication of this paper.

\section{References}

[1] Kim, G., Shin, B. and Lee, H.G. (2009) Understanding Dynamics between Initial Trust and Usage Intentions of Mobile Banking. Information Systems Journal, 19, 283-311. https://doi.org/10.1111/j.1365-2575.2007.00269.x

[2] Alalwan, A.A., Dwivedi, Y.K. and Rana, N.P. (2017) Factors Influencing Adoption 
of Mobile Banking by Jordanian Bank Customers: Extending UTAUT2 with Trust. International Journal of Information Management, 37, 99-110.

[3] Chong, A.Y.L. (2013) Predicting m-Commerce Adoption Determinants: A Neural Network Approach. Expert Systems with Applications, 40, 523-530.

https://doi.org/10.1016/j.eswa.2012.07.068

[4] Chong, A.Y.L., Ooi, K.B., Lin, B. and Bao, H. (2012) An Empirical Analysis of the Determinants of $3 \mathrm{G}$ Adoption in China. Computers in Human Behavior, 28, 360-369. https://doi.org/10.1016/j.chb.2011.10.005

[5] Lin, H.F. (2013) Determining the Relative Importance of Mobile Banking Quality Factors. Computer Standards \& Interfaces, 35, 195-204.

https://doi.org/10.1016/j.csi.2012.07.003

[6] Cruz, P., Neto, L.B.F., Munoz-Gallego, P. and Laukkanen, T. (2010) Mobile Banking Rollout in Emerging Markets: Evidence from Brazil. International Journal of Bank Marketing, 28, 342-371. https://doi.org/10.1108/02652321011064881

[7] Lee, H., Harindranath, G., Oh, S. and Kim, D.J. (2015) Provision of Mobile Banking Services from an Actor-Network Perspective: Implications for Convergence and Standardization. Technological Forecasting and Social Change, 90, 551-561. https://doi.org/10.1016/j.techfore.2014.02.007

[8] Brown, I., Cajee, Z., Davies, D. and Stroebel, S. (2003) Cell Phone Banking: Predictors of Adoption in South Africa-An Exploratory Study. International Journal of Information Management, 23, 381-394.

[9] Varma, A., Bhalotia, K. and Gambhir, K. (2018) Innovating for Competitive Advantage: Managerial Risk-Taking Ability Counterbalances Management Controls. Journal of Management and Governance. https://doi.org/10.1007/s10997-018-9422-z

[10] Hanafizadeh, P., Behboudi, M., Koshksaray, A.A. and Tabar, M.J.S. (2014) Mobile-Banking Adoption by Iranian Bank Clients. Telematics and Informatics, 31, 62-78. https://doi.org/10.1016/j.tele.2012.11.001

[11] Laukkanen, T., Sinkkonen, S., Kivijärvi, M. and Laukkanen, P. (2007) Innovation Resistance among Mature Consumers. Journal of Consumer Marketing, 24, 419-427. https://doi.org/10.1108/07363760710834834

[12] Wessels, L. and Drennan, J. (2010) An Investigation of Consumer Acceptance of M-Banking. International Journal of Bank Marketing, 28, 547-568. https://doi.org/10.1108/02652321011085194

[13] Yang, A.S. (2009) Exploring Adoption Difficulties in Mobile Banking Services. Canadian Journal of Administrative Sciences/ Revue Canadienne des Sciences de I'Administration, 26, 136-149.

[14] Venkatesh, V., Morris, M.G., Davis, G.B. and Davis, F.D. (2003) User Acceptance of Information Technology: Toward a Unified View. MIS Quarterly, 27, 425-478. https://doi.org/10.2307/30036540

[15] Gnyawali, D.R. and Park, B.J. (2009) Co-opetition and Technological Innovation in Small and Medium-Sized Enterprises: A Multilevel Conceptual Model. Journal of Small Business Management, 47, 308-330.

[16] Moghavvemi, S., Mohd Salleh, N.A. and Standing, C. (2016) Entrepreneurs Adoption of Information System Innovation: The Impact of Individual Perception and Exogenous Factors on Entrepreneurs Behavior. Internet Research, 26, 1181-1208. https://doi.org/10.1108/IntR-01-2014-0024

[17] Muñoz-Leiva, F., Climent-Climent, S. and Liébana-Cabanillas, F. (2017) Determi- 
nants of Intention to Use the Mobile Banking Apps: An Extension of the Classic TAM Model. Spanish Journal of Marketing, 21, 25-38. https://doi.org/10.1016/j.sjme.2016.12.001

[18] Franquesa, J. and Brandyberry, A. (2009) Organizational Slack and Information Technology Innovation Adoption in SMEs. International Journal of E-Business Research, 5, 25-48. https://doi.org/10.4018/jebr.2009010102

[19] Spencer, A.J., Buhalis, D. and Moital, M. (2012) A Hierarchical Model of Technology Adoption for Small Owner-Managed Travel Firms: An Organizational Decision-Making and Leadership Perspective. Tourism Management, 33, 1195-1208. https://doi.org/10.1016/j.tourman.2011.11.011

[20] Escobar-Rodríguez, T. and Carvajal-Trujillo, E. (2014) Online Purchasing Tickets for Low Cost Carriers: An Application of the Unified Theory of Acceptance and Use of Technology (UTAUT) Model. Tourism Management, 43, 70-88. https://doi.org/10.1016/j.tourman.2014.01.017

[21] Williams, M.D., Rana, N.P., Dwivedi, Y.K. and Lal, B. (2011) Is UTAUT Really Used or Just Cited for the Sake of It? A Systematic Review of Citations of UTAUT's Originating Article.

[22] Zhou, T., Lu, Y. and Wang, B. (2010) Integrating TTF and UTAUT to Explain Mobile Banking User Adoption. Computers in Human Behavior, 26, 760-767. https://doi.org/10.1016/j.chb.2010.01.013

[23] Riffai, M.M.M.A., Grant, K. and Edgar, D. (2012) Big TAM in Oman: Exploring the Promise of On-Line Banking, Its Adoption by Customers and the Challenges of Banking in Oman. International Journal of Information Management, 32, 239-250. https://doi.org/10.1016/j.ijinfomgt.2011.11.007

[24] Venkatesh, V., Thong, J.Y. and Xu, X. (2012) Consumer Acceptance and Use of Information Technology: Extending the Unified Theory of Acceptance and Use of Technology. MIS Quarterly, 36, 157-178.

[25] Dodds, W.B., Monroe, K.B. and Grewal, D. (1991) Effects of Price, Brand, and Store Information on Buyers' Product Evaluations. Journal of Marketing Research, 28, 307-319. https://doi.org/10.2307/3172866

[26] Kim, T.G., Lee, J.H. and Law, R. (2008) An Empirical Examination of the Acceptance Behaviour of Hotel Front Office Systems: An Extended Technology Acceptance Model. Tourism Management, 29, 500-513. https://doi.org/10.1016/j.tourman.2007.05.016

[27] Birnberg, J.G. and Snodgrass, C. (1988) Culture and Control: A Field Study. Accounting, Organizations and Society, 13, 447-464. https://doi.org/10.1016/0361-3682(88)90016-5

[28] https://rbi.org.in/scripts/bs_viewcontent.aspx?Id=2035

[29] Chin, W.W. (1998) The Partial Least Squares Approach to Structural Equation Modeling. Modern Methods for Business Research, 295, 295-336.

[30] DeVellis, R.F. (2016) Scale Development: Theory and Applications (Vol. 26). Sage, Thousand Oaks.

[31] Churchill, G.A. and Iacobucci, D. (2002) Marketing Research: Methodological Foundations. Harcourt College Publishers, San Diego, 14.

[32] Podsakoff, P.M., MacKenzie, S.B., Lee, J.Y. and Podsakoff, N.P. (2003) Common Method Biases in Behavioral Research: A Critical Review of the Literature and Recommended Remedies. Journal of Applied Psychology, 88, 879-903. https://doi.org/10.1037/0021-9010.88.5.879 
[33] Hulland, J. (1999) Use of Partial Least Squares (PLS) in Strategic Management Research: A Review of Four Recent Studies. Strategic Management Journal, 20, 195-204. https://doi.org/10.1002/(SICI)1097-0266(199902)20:2<195::AID-SMJ13>3.0.CO;2-7

[34] Ringle, C.M., Wende, S. and Becker, J.M. (2015) SmartPLS 3. SmartPLS GmbH, Boenningstedt. http://www.smartpls.com

[35] Lowry, P.B. and Gaskin, J. (2014) Partial Least Squares (PLS) Structural Equation Modeling (SEM) for Building and Testing Behavioral Causal Theory: When to Choose It and How to Use It. IEEE Transactions on Professional Communication, 57, 123-146. https://doi.org/10.1109/TPC.2014.2312452

[36] Ali, M. and Park, K. (2016) The Mediating Role of an Innovative Culture in the Relationship between Absorptive Capacity and Technical and Non-Technical Innovation. Journal of Business Research, 69, 1669-1675. https://doi.org/10.1016/j.jbusres.2015.10.036

[37] Fornell, C. and Larcker, D.F. (1981) Evaluating Structural Equation Models with Unobservable Variables and Measurement Error. Journal of Marketing Research, 18, 39-50. https://doi.org/10.2307/3151312

[38] Sarstedt, M., Ringle, C.M., Smith, D., Reams, R. and Hair, J.F. (2014) Partial Least Squares Structural Equation Modeling (PLS-SEM): A Useful Tool for Family Business Researchers. Journal of Family Business Strategy, 5, 105-115. https://doi.org/10.1016/j.jfbs.2014.01.002

[39] Field, A. (2009) Discovering Statistics Using SPSS. 3rd Edition, Sage Publication, London.

[40] Preacher, K.J. and Hayes, A.F. (2008) Asymptotic and Resampling Strategies for Assessing and Comparing Indirect Effects in Multiple Mediator Models. Behavior Research Methods, 40, 879-891. https://doi.org/10.3758/BRM.40.3.879

[41] Henseler, J. and Sarstedt, M. (2013) Goodness-of-Fit Indices for Partial Least Squares Path Modeling. Computational Statistics, 28, 565-580. https://doi.org/10.1007/s00180-012-0317-1

[42] Morris, M.G., Venkatesh, V. and Ackerman, P.L. (2005) Gender and Age Differences in Employee Decisions about New Technology: An Extension to the Theory of Planned Behavior. IEEE Transactions on Engineering Management, 52, 69-84. https://doi.org/10.1109/TEM.2004.839967

[43] Sharma, S.K., Govindaluri, S.M. and Al Balushi, S.M. (2015) Predicting Determinants of Internet Banking Adoption: A Two-Staged Regression-Neural Network Approach. Management Research Review, 38, 750-766. https://doi.org/10.1108/MRR-06-2014-0139

[44] Sharma, S.K., Govindaluri, S.M., Al-Muharrami, S. and Tarhini, A. (2017) A Multi-Analytical Model for Mobile Banking Adoption: A Developing Country Perspective. Review of International Business and Strategy, 27, 133-148. https://doi.org/10.1108/RIBS-11-2016-0074

[45] Davis, F.D., Bagozzi, R.P. and Warshaw, P.R. (1989) User Acceptance of Computer Technology: A Comparison of Two Theoretical Models. Management Science, 35, 982-1003. https://doi.org/10.1287/mnsc.35.8.982

[46] Ajzen, I. (1991) The Theory of Planned Behavior. Organizational Behavior and Human Decision Processes, 50, 179-211. https://doi.org/10.1016/0749-5978(91)90020-T

[47] Rogers, E.M. (2010) Diffusion of Innovations. Simon and Schuster. 
[48] Lee, M.S., McGoldrick, P.J., Keeling, K.A. and Doherty, J. (2003) Using ZMET to Explore Barriers to the Adoption of $3 \mathrm{G}$ Mobile Banking Services. International Journal of Retail \& Distribution Management, 31, 340-348.

https://doi.org/10.1108/09590550310476079 